\title{
Standards for perinatal education part 1
}

\section{MS Richter, DCur, Department of Nursing Science, University of Pretoria}

\section{Abstract}

Quality control in perinatal education is imperative, with the purpose to deliver a high quality and appropriate healthcare service to the family in the perinatal period. The purpose of this study was to develop valid standards for perinatal education in South Africa.

To reach this goal, the study proceeded as follows:

Development phase

concepts were developed for perinatal education, the concepts were logically systematised and formulated in concept standards,

the standards were presented for peer group review with the purpose of refinement and further development.

Quantification phase

the statistical validity of the standards was deter$\mathrm{mined} /$ calculated.

After completion of the study the researcher reached the conclusion that quality perinatal education must adhere to the following standards:

- A philosophy for perinatal education must exist.

- The perinatal facilitator must be a well trained professional person, and must possess certain personal traits.

- The perinatal education style/method must adapt according to the client's socio-economic status, age, marital status and needs.

- $\quad$ The perinatal facilitator must make use of acknowledged teaching methods and techniques in order to facilitate learning.

- $\quad$ The perinatal education must comply with certain minimum requirements in order to make it acces -sible and acceptable to the client.

- The perinatal facilitator must complete a preparatory phase before she is allowed to give education.

- A perinatal education programme must have a curriculum that can be adapted to the client's circum -stances.

- $\quad$ Perinatal education must be presented purposefully.

- $\quad$ The end result of perinatal education must focus on a healthy baby and a healthy, empowered mother, family and community.

\section{Opsomming}

Gehalteversekering is noodsaaklik ten opsigte van perinatale onderrig, met die doel om 'n hoë gehalte en toepaslike gesondheidsorg te lewer aan die gesin in die perinatale periode. Die doel van hierdie studie was om geldige standaarde vir perinatale onderrig te ontwikkel in Suid-Afrika.

Om hierdie doel te bereik, het die studie as volg verloop: Ontwikkelingsfase

- $\quad$ konsepte vir perinatale onderrig is ontwikkel,

- die konsepte is logies gesistematiseer en geformuleer in konsepstandaarde, die standaarde is voorgelê vir portuurgroepbeoordeling met die doel om die standaarde te verfyn en verder te ontwikkel.

Kwantifiseringsfase

die statistiese geldigheid van die standaarde is in hierdie fase verreken.

Na voltooiing van die studie het die navorser tot die gevolgtrekking gekom dat kwaliteit perinatale onderrig aan die volgende standaarde moet voldoen:

- $\quad$ 'n Geskrewe filosofie moet bestaan vir perinatale onderrig.

- Die perinatale fasiliteerder moet ' $n$ professionele persoon wees wat goed opgelei is, en aan sekere persoonlikheids- en gedragsvereistes voldoen.

- Die perinatale onderrigstyl/metode moet aanpas na gelang die kliënt se sosio-ekonomiese status, ouderdom, huwelikstatus en behoeftes.

- Die perinatale fasiliteerder moet gebruik maak van erkende onderrigtegnieke en metodes om leer te fasiliteer.

- Die perinatale onderrigfasiliteit moet aan sekere minimumvereistes voldoen om dit toeganklik en aanvaarbaar vir die kliënt te maak.

- $\quad$ Die perinatale fasiliteerder moet ' $\mathrm{n}$ voorbereidingsfase voltooi voordat sy toegelaat word om perinatale onderrig te gee.

- $\quad$ 'n Perinatale onderrigprogram moet beskik oor 'n kurrikulum wat aangepas word na gelang van die kliënt se omstandighede.

- $\quad$ Perinatale onderrig moet doelgerig aangebied word.

- Die eindresultaat van perinatale onderrig moet fokus op ' $n$ gesonde baba, en 'n gesonde, bemagtigde moeder, gesin en gemeenskap.

\section{Introduction}

Quality control is imperative when delivering a high quality and appropriate health care service to the family during the perinatal period. The purpose of this study was to develop valid standards for perinatal education in South Africa. 


\section{Background and rationale to the study}

The unique multicultural composition of the South African population poses a challenge to perinatal education. A small part of the population has access to high technology medical services, while the biggest part of the population lives under poor socio-economic circumstances with limited access to any medical services. The maternal and perinatal mortality figure is high, and there is a high incidence of low birth babies. The South African health system is also characterised by few health personnel and insufficient services regarding accessibility, availability and affordability (ANC 1994: 42 - 43).

The part of the South African population with a limited access to health services is characterised by a low socio-economic status and a high incidence of unmarried women and adolescent mothers. According to Redman, Oak, Booth, Jensen and Saxton (1991: 315) it has been proven unlikely that young unmarried women and women of low socio-economic status will attend formal perinatal teaching. Obstacles like poor housing, low income and social isolation are also reasons why these women do not attend perinatal education classes (Cliff \& Deery 1997: 144). Adolescent mothers have a high risk of developing psychological and maternal behaviour problems. These problems can negatively influence the mother's life and the baby's health. Adolescent mothers also experience a high degree of stress, are less responsive and sensitive in interaction with their babies and provide less stimulation to the baby than older mothers (Lesser, Andersin \& Koniak-Griffen 1998: 7). These mothers' babies are inclined to have poorer health: it is unlikely that the mothers will make use of preventative behaviour, continue with breastfeeding or have their babies fully immunized.

Different recruitment and presentation techniques need to be used to get a high attendance and interest from adolescent women and women of a low socio-economic status (Rutter, Quine 1990: 597, Condon \& Hilton 1988: 114, Hitchcock \& Coy 1988: 114 - 117, Blaze-Temple, Bins \& Baldy 1988: 55, Hancock 1994: 13).

In South Africa, there is a tendency to discharge the mother early after she has delivered her baby. This tendency places extra pressure on perinatal education (Herbert 1994: 36). The needs of client education in the perinatal period become a bigger priority and it is accepted as an essential part of maternal and child health care. The private sector in South Africa functions according to the new management style. This results in managed health care that aims at cost effective management, and it entails the early discharge of the mother and her baby (Bendell 1997: 212). In the public sector, just as well, early discharge of the mother and baby happens because of a shortage of manpower and facilities. The mother and baby are often discharged without the opportunity to receive health education.

Perinatal education is extremely important and can play an important role in the reduction of perinatal morbidity and mortality. The five main causes of maternal deaths in South Africa are: hypertension complication during pregnancy, HIV/AIDS,

bleeding,

sepsis is related to pregnancy,

existing medical conditions

Other causes of maternal deaths (a delay in obtaining medical help; multiple pregnancies; the poor attendance of antenatal clinics; the behaviour of pregnant women) can be addressed during quality perinatal education. Catford and Nutbean (1984: 38) state that health education (in this case perinatal education) is aimed at protecting or improving health through a voluntary change in behaviour. Personal education and development improve knowledge concerning health, the client's selfimage that leads to self-empowerment. Dunn (1995: 210) confirms this statement and says that access to health education should be a basic human right.

Sturrock and Johnson (1990: 85) have the viewpoint that pregnant parents should get all the help possible. Brown (1982: 11) sums it up by saying: "meeting new parents' knowledge needs has become an increasingly important nursing priority. The focus on maternity-client teaching and discharge planning is due to:

increased acknowledgement and understanding by medical personnel of skills required of new parents, and

increased public awareness of the importance of health care education."

No perinatal education standards exist in South Africa. Various health professions are allowed to teach perinatal education without a standardized curriculum or standards that are applicable to the perinatal educator. It is imperative to ensure quality regarding perinatal education to deliver a high quality and appropriate health care system. Quality assurance is a process of developing standards to improve the practice (Muller, Van Huysteen \& Bruwer 1991: 6). Standards serve as clinical guidelines. They must be systematically developed to allow the practitioner (in this case the perinatal educator) to help the client with decision making concerning appropriate health care in specific clinical situations (McMahon 1999: 33).

The World Health Organization (1982: 6) has the viewpoint that standards direct the practitioner's practice. They should be formulated within the context of a country's culture, philosophy, ethical norms and economical and political development. The formulation of standards is specifically the responsibility of each health profession and therefore also the responsibility of the nursing profession (Muller et al 1991:6).

Standards should be formulated concerning: who must give perinatal education; when perinatal education must be given; what the length of the course should be; what the size of the classes should be; and what the curriculum of the perinatal education course should be (Zwelling 1996: 431). 


\section{Problem statement}

No formal, written standards for perinatal education exist in South Africa. The question arises:

What should the standards for perinatal education be?

\section{Research objectives}

The purpose of the study was to develop standards for perinatal education in South Africa. The following objectives were set to reach this purpose:

to develop appropriate concepts for perinatal education with the use of grounded theory methodology; to develop concept standards based on the developed concepts;

to determine the content validity of the standards on national level; and

to verify the standards in practice, based on the opinions of perinatal clients.

\section{Paradigmatic perspective of the study}

The researcher made use of the Theory for Health Promotion in Nursing (Randse Afrikaans University 1999). This theory aims to promote the health of the individual, the family, the group and the community.

\section{Methodology Research design}

An exploratory, descriptive qualitative research design was used to formulate standards for perinatal education.

\section{Research technique}

The research technique for the formulation of nursing standards consists of two phases, namely the developmental phase and the quantification phase.

\section{Developmental phase}

The developmental phase is divided into: PHASE I

$$
\begin{aligned}
& \text { the development and generation of concepts for peri- } \\
& \text { natal education: } \\
& \text { a logical systematization of these concepts and the } \\
& \text { formulation of concept standards; }
\end{aligned}
$$

PHASE II

- $\quad$ submission for peer group evaluation to refine and further develop the standards and the content validity of the standards (Muller 1990: 53).

\section{Quantification phase}

The purpose of the quantification phase is to determine the content validity of the standards on national level. The statistical validity of the standards was also determined during this phase. This step entails the assertion by a number of experts that the standards are content valid. The number of experts often depends on how many accessible and agreeable persons the researcher can identify and not so much on a population estimation principle (Lynn 1986: 383). The standards are presented in the form of a questionnaire. The researcher expects the respondents, as part of the determination of the content validity, to indicate areas of omission, improvement and modification.

\section{Data collection: Development phase: Phase I \\ Purpose}

The purpose of this phase of the study was to develop concepts for perinatal education.

\section{Data gathering}

The researcher started formulating concepts by determining the reality within the perinatal teaching field. Grounded theory was used during the development phase to develop concepts for perinatal education. Grounded theory methodology is a qualitative method which uses a systematic set of procedures to develop an inductively derived grounded theory about a phenomenon (De Vos 1998: 265). Grounded theory offers a systematic method for collecting, organizing and analysing data from the empirical world of perinatal educational practice. It embraces multiple realities and allows concepts to be developed from practice. As such, grounded theory enhances the understanding of the world of the perinatal educator and the perinatal client.

This is concept formulation that is grounded in reality. It enables nurses to obtain rich data and to formulate explanatory concepts of reality. Grounded theory also explains the gap between practice and theory, and allows theory development on a social level to bring forth advanced practice and improved patient care. This is a theory of symbiotic interaction that focuses on the meaning of the events of people in their natural environment (Sheldon 1998: 48).

The grounded theory approach in the development of concepts for perinatal education is suited to the purpose of this study because:

the researcher wanted to discover relevant concepts for perinatal education and the relationship between the concepts that remained connected to or grounded in the data,

the researcher wanted to categorize the concepts in a new rather than a standard way,

the danger existed that if the researcher started with concepts that have already been identified, it might have stood in the way of discovering new concepts on perinatal education (Strauss\& Corbin 1990: 49), "also underlying this approach to qualitative research is the assumption that all the concepts pertaining to a given phenomenon have not yet been identified, at least not in this population or place" (De Vos 1998: 268), it is, according to Smith and Biley (1997: 18) especially useful in nursing research. "Nurse scientists who use grounded theory find it ideal for teaching nursing problems... because the grounded theory sci entist generates from the data rather than applying a theory constructed by someone else or from another 
data source; the generated theory remains connected to or grounded in the data."

Grounded theory methodology emphasizes that concepts must develop from data, and not previous knowledge. The action that leads to conceptualization must also be described. The purpose of the discovery process is to theoretically describe the basic social processes central or problematic to the participants in the study. Grounded theory methodology encourages the researcher to look for data rather than look at data, leading to the emergence of concepts (Robrechts 1995: 171).

Grounded theory methodology, in this study, made use of the explanatory model to develop concepts. The explanation informed the researcher of the relation between action and outcome in specific circumstances in a specific context. Concepts represented groups of dimensions that embraced reality. Naming these dimensions provided a conceptual way to communicate on the reality of the research field (Schatzman 1991: 303 314).

The dimensions did not form a comprehensive whole during the development phase of the study. The researcher had to form a selective perspective of all the dimensions involved in the research field. This perspective became the theme that configured and represented the theoretical explanation of the research field. The process was a random sampling of systematic investigation, acceptance or rejection of all the dimensions, within the boundaries of the research. Grounded theory is a repetitive process: the researcher returned constantly to data sources, checking aspects of emerging interpretations and to gather new data. This is referred to as the process of constant comparative analysis (Smith \& Biley 1997: 18). Prevailing perspectives guided the dimensions. This concurred with the purpose of grounded theory methodology to generate concepts that accounted for behaviour relevant and problematic to those involved (Robrecht 1991: 175).

Grounded theory provided a means of studying human behaviour and interaction. It created a new perspective on, and an understanding of common behaviour (Sheldon 1998: 48). A variety of literature is available on women's experiences of pregnancy and the post partum period. The researcher tried not to replicate it, but to develop original concepts. This, specifically, is why the grounded theory methodology suited this study.

\section{Generation of appropriate concepts}

The researcher made use of different data gathering methods, namely focus groups, narratives and one-on-one interviews.

\section{Focus groups}

The purpose of focus groups in this study was to get all the role-players involved with perinatal education involved developing the concepts. The focus group is a qualitative research method that is used to obtain valuable data that can not be obtained by any other technique. It is a purposeful discussion in a non-threatening environment that makes use of a carefully planned semi-structured interview on a specific topic. The discussions host between 4 and 12 individuals with similar backgrounds and communal interests. The focus group interviews allowed the researcher to develop inductively derived concepts that are grounded in the reflection of the participants" knowledge (De Vos 1998: 314, McDaniels \& Bach 1994: 4).

The rationale for using focus groups as data gathering method in this study was:

- the individual, and in this case the perinatal client and facilitator, is an important source of information;

- it is a flexible data gathering method to refine or rede fine concepts during the research process;

- it is an excellent data gathering method to determine certain feelings concerning perinatal education;

- the researcher plays passive role, preventing that the researcher's predetermined ideas influence the participants;

- $\quad$ group interaction is enhanced by placing perinatal clients and facilitators together, helping with the generation of ideas (this would not be possible with another data gathering method);

- the participants statements could verify or be discussed it in more depth,

- $\quad$ it is an effective method when working with special groups like children and illiterate adults (in this case women of low socio-economic status and pregnant teen -agers);

- $\quad$ new ideas and concepts are stimulated with to learn more from the participants' opinions and experiences (Stewart \& Shamdasani 1990: 15; Betts, Baranowski \& Hoerr 1996: 279 - 280).

Semi-structured interviews were used. The focus group started with a short description of the purpose of the study. Semistructured interviews gave the participants the opportunity to move more freely from concept to concept, to follow up leads and to spend more time on important concepts.

Theoretical sampling was used, where the participants were chosen based on their knowledge of the phenomenon (Smith \& Biley 1997: 20-21).

Five focus groups were conducted in this study, namely:

- $\quad$ Focus group 1: Clients from a low socio-economic background

- $\quad$ Focus group 2: Clients from a high socio-economic background

- $\quad$ Focus groups 3 and 4: Perinatal educators

- $\quad$ Focus group 5: Unwed pregnant teenage girls

\section{Narratives}

The purpose of using narratives in this study was to discover what information is important when perinatal education is given, in other words, what should be included in a curriculum for perinatal education.

The researcher asked participants to keep a reflective diary of the health promoting education they were giving on a daily 
basis, and the questions they had to answer during the perinatal period. Nursing personnel of public and private hospitals were used. The data was regarded as saturated when no new data came up and data started repeating.

\section{One-on-one interviews}

The researcher identified gaps in certain parts of the data and used one-on-one interviews to fill the gaps. The researcher used unstructured interviews with a schedule. The schedule guided the researcher to answer themes that were not saturated. The advantage of using one-on-one interviews is that the response is high and more complex questions can be asked. The researcher can also verify questions that are not well understood (Wilson, Roe \& Wright 1998: 315).

\section{Data analysis}

Different reasoning strategies were used in the analysis of the data, for example inductive reasoning, synthesis and bracketing.

\section{Formation of concept standards}

After the generation of construct dependability, the concepts for perinatal education were systematized. The traditional listing method was used. According to Muller (1990: 52) the listing of standards and criteria is a process according to which standards and criteria are listed in a logical way without any alternatives.

\section{Submission for peer review}

The purpose of peer review is to refine and further develop the standards. The experts were expected to evaluate the standards. A short debate was held on each standard until a group consensus was reached. A structured questionnaire was handed out to each participant to verify their expertise and to obtain their professional information. The criteria that was followed here was expertise, and the following experts were used:

registered nurses knowledgeable in the field of perinatal education with more than 5 years experience in this field, and

lecturers of Departments of Nursing Science at Universities that lecture neonatology and midwifery.

\section{Quantification phase}

The statistical validity of the standards was determined during this phase. The index of the content validity was statistically calculated. Lynn (1986: 384) orders the use of a 4-point scale: "the 4-point scale is preferable because it does not include the ambivalent middle rating common in odd number rating scales. Using a 4-point scale should provide the instrument developer with sufficiently delineated information upon which to calculate a meaningful index of content validity."

The following 4-point ordinal Likert scale rating was used:

- Irrelevant, not applicable at all

- Vague/applicability queried
- $\quad$ Applicable, but needs some reformulation

- $\quad$ Complete, distinct, well-formulated and highly appli -cable

An item (standard and required criteria) that obtained an average content validity index of 3,0 or 4,0 and a standard deviation of $\leq 1$, was accepted as valid (Lynn 1986: 335).

\section{Population and sampling}

The researcher used clients in the perinatal period, perinatal facilitators and lecturers in neonatal nursing, midwifery and community nursing. The rationale for using perinatal clients during this phase of the study is that the standards are written with their help; the researcher wanted to determine if the clients agreed with the content of the standards. According to Tilden, Nelson and May (1990: 174) "lay experts (are) the best critics of abstract words or unclear phrasing and the best judges of the validity of the link between ideas and their expression in items."

\section{Trustworthiness of the study}

Guba's model was used to ensure the study's trustworthiness. The strategies used were:

\section{Credibility strategies}

Credibility improves the truth value of the study. This was ensured by triangulating the data sources, prolonging engagement in the perinatal education field, member checking and having group discussions with peers (Krefting 1991: 217).

All role-players involved in perinatal education (perinatal clients and professional people) were also involved in the developmental and quantification phases of the study. This improves the credibility of the study.

\section{Transferability strategies}

The gathered data was representative because all the role-players were involved in the developmental and validation phases of the study. The study was done contextually in terms of geography (South Africa) and research field (clients in the perinatal period and professional people involved in perinatal education), both in the developmental and quantification phases.

\section{Dependability strategies}

The researcher ensures reliability by giving a detailed description of the methods followed in this study. Such a dense description of methods provides information on how repeatable the study might be. A known method of developing standards was followed.

\section{Confirmability strategies}

Confirmability was ensured by giving a detailed description of the research process, triangulating the data gathering sources, refining discussion with experts and validating the standards on national level (Krefting 1991: 221). 


\section{Conclusions}

On completion of the study the researcher reached the conclusion that quality perinatal education should measure up to the following standards:

\section{Process standards}

- A written philosophy for perinatal education must exist.

- The perinatal facilitator must be a well-trained professional person, and must possess certain personal traits and behavioural attributes.

- The perinatal education style/method must adapt according to the client's socio-economic status, age, marital status and needs.

- The perinatal facilitator must make use of acknowl edged teaching techniques and methods to facilitate learning.

\section{Structural standards}

- The perinatal education must comply with certain minimum requirements to make it accessible and acceptable to the client.

- The perinatal facilitator must complete a preparatory phase before she is allowed to give education.

A perinatal education programme must have a curriculum that can be adapted to the client's circumstances.

\section{Outcome standards}

- Perinatal education must be presentea purpasefully

- The end result of perinatal education must focus on healthy baby and a healthy and empotyered protner, family and community.

\section{Recommendations}

Recommendations are based on the findings of the developmental and quantification phases of the study.

\section{Clinical practice}

It is recommended that:

the standards are implemented;

the standards are used as clinical guidelines when perinatal education is given;

the standards are used to evaluate the clinical practice of the perinatal educator (self-evaluation and peer group evaluation).

\section{Education}

The following recommendations are made:

An educational programme for perinatal facilitators should be developed within the South African context to thereby better the quality of perinatal education. The method of quality improvement and the method of formulating nursing standards should be part of all professional persons' (involved with perinatal education) training.

\section{Research}

The following recommendations are made:

Secondary analysis of the data must be done to determine if there is a significant difference in the responses of the perinatal clients and the perinatal facilitators that were involved in this study. This must be done to determine if the needs of the perinatal client are in agreement with what the perinatal facilitator thinks the client's needs are.

It must be tested whether the implementation of these standards make a difference in the quality of perinatal education.

\section{Conclusion}

The purpose of this study was reached. Standards for perinatal education were developed for the South African context with the help of perinatal clients and professional people involved with perinatal education. The standards must now be implemented and it must be determined whether they contribute to the quality of perinatal education. All professionals involved in perinatal education are advised to empower themselves with knowledge that leads to better educational methods when working with the family during the perinatal period.

\section{References}

SANC 1994: The Reconstruction and Development Programme. Johannesburg: Umanyana Publications.

BENDELL, A 1997: Health care in the 1990's: Changes in Health Care Delivery Models for Survival. JOGNN. 26(2): 212 216.

BETTS, NM; BARANOWSKI, T \& HOERR, SL 1996: Recommendations for Planning and Reporting Focus group Research. Journal of Nutrition Education. 28(5): 279 - 281.

BLAZE-TEMPLE, D, BINNS, W \& BALDY, DP 1988: Parental perceptions of measles. Community Health Studies. 12:5562.

BROWN, B 1982: Maternal-Patient Teaching - A Nursing Priority. JOGN. 11: 11 - 14.

CATFORD, J \& NUTBEAN, D 1984: Towards a definition of health education and health promotion. Health Education Journal, 43(2 \& 3): 38 .

CLIFF, D \& DEERY, R 1997: Too much like school: social class, age, marital status and attendance/non-attendance of antenatal classes. Midwiferv. 13: $139-145$.

CONDON, JJ \& HILTON, CA 1988: A comparison of smoking and drinking behaviours in pregnant women: Who abstained and why? Medical Journal of Australia. 148: 114- 117.

DE VOS, AS 1998: Research at Grass Roots. Goodwood: 
DUNN, PM 1995: Major ethical problems confronting perinatal care around the world. International Journal of Gynecology \& Obstetrics. 51: $205-210$.

HANCOCK, A 1994: How effective is antenatal education? Modern Midwifery. 4(5): 13-15.

HERBERT, P 1994: Support of first-time mothers in the three months after birth. Nursing Times. 90(24): $36-37$

HITCHCOCK, NE \& COY, JF 1988: Infant-feeding practices in Western Australia and Tasmania: A joint survey, 1984 1985. Medical Journal of Australia. 148: 114-117

KREFTING, L 1991: Rigor in Qualitative Research: The Assessment of Trustworthiness. The American Journal of Occupational Therapy. 45(3): $214-222$.

LESSER, J., ANDERSON, N.L.R. \& KONIAK-GRIFFIN, D. 1998: "Sometimes You Don't Feel Ready to Be an Adult or a Mom:" The Experience of Adolescent Pregnancy. Journal of child and adolescent psychiatric nursing. 11(1): 7-16.

LYNN, MR 1986: Determination and Qualification of Content Validity. Nursing Reseach. 35(6): $382-385$.

MCDANIELS, RW \& BACH, CA 1994: Focus Groups: A Data- gathering Strategy for Nursing research. Nursing Science Ouarterly. (1): $4-5$.

MCMAHON, A 1999: Evidence-based nursing guidelines on the web. Nursing Standard. 14(5): 33.

MULLER M 1990: Navorsingmetodologie vir die formulering van Verpleegstandaarde. Curationis. $13(3+4): 49-55$.

MULLER, ME; VANHUYSTEEN, MC \& BRUWER, AM 1991: Verpleegstandaarde vir privaathospitale. Curationis. 14(3): 614.

TILDEN, VP; NEISON, CA \& MAY, BA 1990: Use of Qualitative Methods to Enhance Content Validity. Nursing Research. $39(3): 172-175$.

REDMAN, S; OAK, S; BOOTH, P; JENSEN, J \& SAXTON, A 1991: Evaluation of an Antenatal Education Programme. Characteristics of Attenders, Changes in Knowledge and Satisfaction of Participants. Australian and New Zealand Journal of Obstetrics and Gvnecologv. 31(4): 310-316.

ROBRECHT, LC 1995: Grounded Theory Evolving Methods. Qualitative Health Research. 5(2): 169- 177.

RUTTER, D R \& QUINE, L 1990: Inequalities in pregnancy outcome: A review of psychosocial and behavioural mediators. Social Science and Medicine. 5: 597 - 604.

SCHATZMAN, L 1991: Dimensional analysis: Notes on an alternative approach to the grounding of theory in qualitative research. In D.R. Mainnes (Ed) Social organization and social
York: Aldine De Gruyter.

SHELDON, L 1998: Grounded theory: issues for research in nursing. Nursing Standard. 12(52): $47-50$.

SMITH, K \& BILEY, F 1997: Understanding grounded theory: principle and evaluation. Nurse Researcher. 4(3): $17-30$.

STEWART, DW \& SHAMDASANI, PN 1990: Focus groups: Theory and Practice. New Park: C A Sage.

STRAUSS, A \& CORBIN, J 1990: Basics of Qualitative Research. Grounded Theory Procedures and Techniques. United States of America: Sage Publications.

STURROCK, WA \& JOHNSON, JA 1990: The Relationship Between Childbirth Education Classes and Obstetric Outcome. Birth, 17(2): $82-85$

WORLD HEALTH ORGANIZATION 1982: Development of Standards of Nursing Practice. Report on a WHO meeting. Sundvollen Norway: WHO.

WILSON, K; ROE, B \& WRIGHT, L 1998: Telephone or face to face interviews? A decision made on the basis of a pilot study. International Journal of Nursing Studies. 35: 314-321.

ZWELLING, E 1996: Childhood Education in the 1990's and Beyond. JOGNN. 25(5): 425-431. 